\title{
"Organizational citizenship behavior and team performance: a multiple level study in Indian higher education institutions"
}

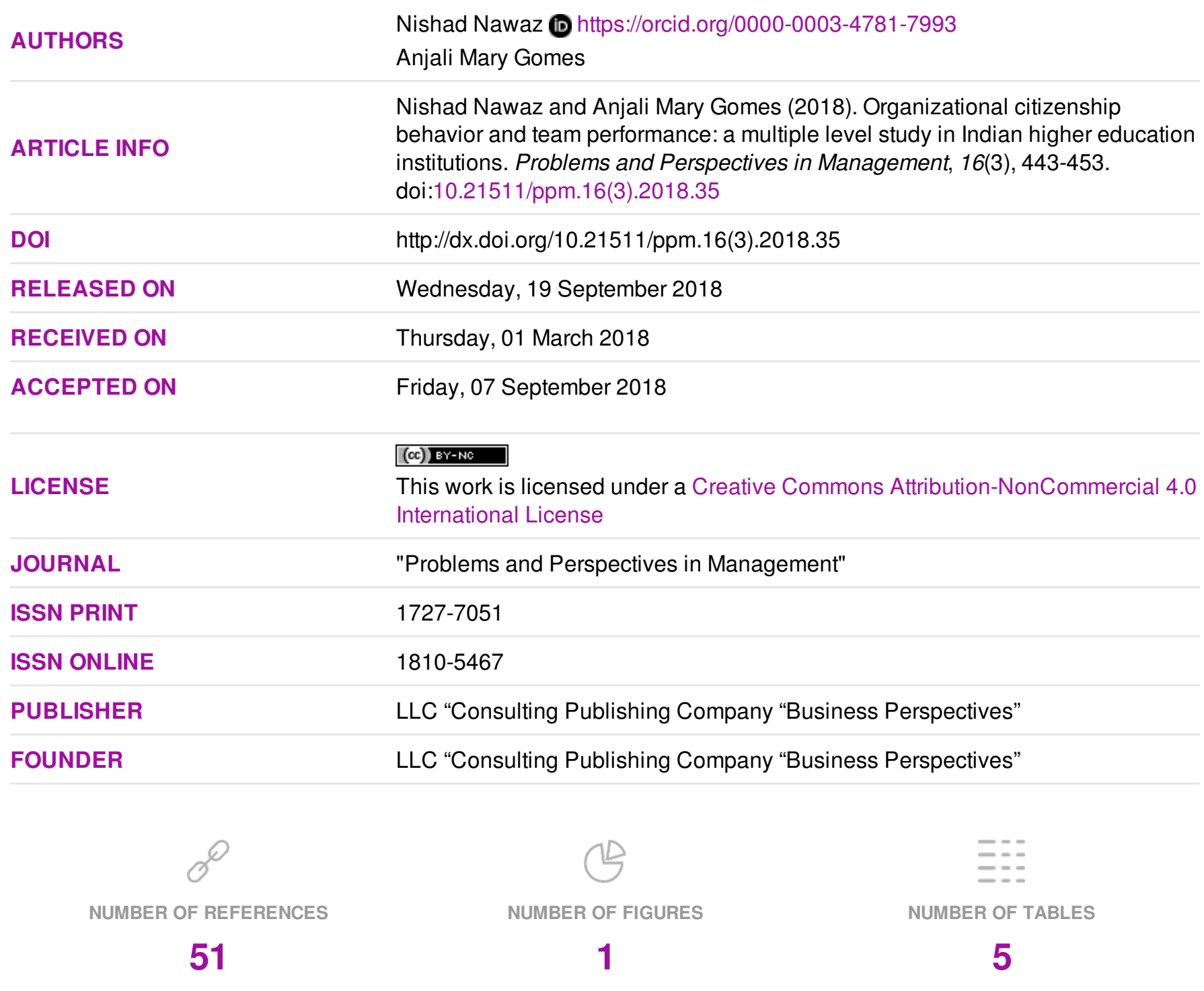

(c) The author(s) 2022. This publication is an open access article. 


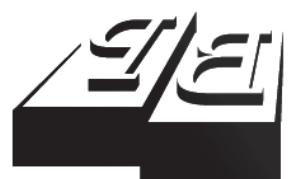

BUSINESS PERSPECTIVES

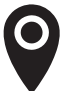

LLC "CPC "Business Perspectives" Hryhorii Skovoroda lane, 10, Sumy, 40022, Ukraine

www.businessperspectives.org

Received on: $1^{\text {st }}$ of March, 2018 Accepted on: $7^{\text {th }}$ of September, 2018

(C) Nishad Nawaz, Anjali Mary Gomes, 2018

Nishad Nawaz, Ph.D., Assistan Professor, College of Business Administration, Kingdom University, Bahrain.

Anjali Mary Gomes, Ph.D., Assistant Professor, College of Business Administration, Kingdom University, Bahrain.

\section{(ㄷ)(1) $(8)$}

This is an Open Access article, distributed under the terms of the Creative Commons Attribution-NonCommercial 4.0 International license, which permits re-use, distribution, and reproduction, provided the materials aren't used for commercial purposes and the original work is properly cited.

\section{ORGANIZATIONAL CITIZENSHIP BEHAVIOR AND TEAM PERFORMANCE: A MULTIPLE LEVEL STUDY IN INDIAN HIGHER EDUCATION INSTITUTIONS}

\begin{abstract}
The prime purpose of this paper is to find out the correlated relations in organizational citizenship behavior, team performance, negative emotions, resource depletion and team member receptivity in higher education institutions in India. The study has been taken on 204 samples with 51 teams from colleges and universities of India, which were gathered by using the questionnaire. The findings have been used for better organizational citizenship behavior, how organizations have to maintain their negative emotions, resource depletion, team members receptivity, team performance to obtain efficient and effective organizational citizenship behavior and team performance in selected higher education institutions in India and considering the variables such as negative emotions, resource depletion, team members receptivity, team performance and organizational citizenship behavior (OCB).
\end{abstract}

\section{Keywords}

team OCB, negative emotions, resource depletion, team performance, team members receptivity, Indian higher education institutions

JEL Classification M10, M12, M19

\section{INTRODUCTION}

From a couple of decades, the organizational citizenship behavior comportment has occupied a paramount position in the literature of organizational theory. Enhancing the organizational efficacy is a strategy, which is paramount in organizations to know the collective skills of human resources. The talent acquisition is changing because of the cultural diversity in employees. In the matter of efficient management of employee behavior, the influence will be not only on the attitude of the employee, but also on organizational performance (Yen \& Niehoff, 2004). Therefore, working under changing environment becomes very vital to the organization (Lee, Dedrick, \& Smith, 1991).

In the present scenario, most of the organizations are dependent regardless of their job description. The employees' behavior hold a greater role in the organizational survival, and it is defined as organizational citizenship behavior (OCB). These concepts have been introduced by Organ and Ryan (1995) and their peers explained them as extra role behavior, spontaneity and civic organizational behavior (Kahn, 1996; Døjbak Håkonsson et al., 2016).

The present study contributes to the literature in many ways. First, the study is done to observe the relationship between the negative emotions, resource depletion and team member reception with team performance. 
The findings enrich our understanding of the antecedents of the negative emotions, resource depletion and team member reception with team performance. Second, this is the first study to investigate through empirical, the results of the study may help scholars, OD practitioners with a lot of information to go deeper insights of behavior of the employees. Finally, the study observed the influence of the team performance on OCB and importance of the team performance in the success of the organization. Besides, employee performance can be enhanced by the following concepts such as negative emotions, resource depletion and team member reception within the Indian context of higher education institutions, in addition to that in what way the behavior of both teaching and non-teaching is related to the team performance.

\section{LITERATURE REVIEW}

\subsection{Organizational citizenship behavior (OCB)}

In this subsection, the existing literature review studies until August 18, 2018 will be presented. A large number of studies in OCB has been done in the USA. Most of the studies have supported the positive relationships between OCB and other indicator of employee and organizational performance (Podsakoff \& MacKenzie, 1997), furthered by Chester I. Barnard (1984). Barnard's conceptions discussed that efficacious organizations call for more role behavior (i.e., comportments that cannot be required from employees for a given job) such as participation in cooperative activities with fellow peers, employee, self-training, and so on. Predicated on these past conceptions, Organ and his colleagues (Bateman, 1983; Organ \& Ryan, 1995) first introduced the concept of OCB. In further discussion, Organ and Konovsky (1989) described OCB as "individual behavior that is discretionary not directly or explicitly by the formal rewards system, and that in the aggregate promotes the efficacious functioning of the organization".

\subsection{OCB and team performance}

Organizational citizenship behavior (OCB) as the categorical deportment of a team member can be considered as team process element that has a significant influence on the team performance. The first author Organ and Ryan (1995) work, especially in the domain of the organizational citizenship behavior which was the first primary data based study on the relationship between the team efficacy and OCB Podsakoff and MacKenzie (1997), and it reveals that the teams that show high power of performance will obtain much more employee contentment and display adequate organizational citizenship behavior.
The organizational citizenship behavior facilitates the team performance by the impact in the context in which the target is taken into consideration to perform better. These demeanors are paramount and instructions are required for the company to develop that they reach desired results by having more efficacious network of communication. In other words, the best practices will enhance more coordination among the employees within the organization.

\subsection{Team performance in Indian context}

As per Singh and Singh (2009) in their work on public and private sector, the managers have opined that they are very supportive as a team member; in addition, they facilitate knowledge to their team, which will enhance the team performance. The team climate is also a critical factor in the context of team performance (Ganesh \& Gupta, 2010). In the organization team, size also plays an important role in team performance (Sharma, Bajpai, \& Holani, 2011; Ton \& Huckman, 2008) their studies concluded that the team average performance, while comparing with other team members, has shown positive significant effect on the team performance.

The study concluded that the relationship between job satisfaction and team performance is correlated with organizational citizenship behavior (Miao \& Kim, 2009). Another piece of work concluded that the cohesion, confrontation and team effectiveness are high in private sector, in addition to that, the team size plays a significant role in team performance (Neha Verma \& Santosh Rangnekar, 2012).

\subsection{Negative emotions}

The study concluded that the team processes and their outcome depends on teams emotional authen- 
ticity (Cho \& Johanson, 2008). The emotions lead to the performance of the employees (Gardner, Fischer, \& Hunt, 2009; Karasawa, 1995), one's native emotion was distributed equally to situations and dispositions. The poor performance of the employee is associated with his high emotions of anxiety and anger (Campo et al., 2016). The paper focused on the following concepts i.e. joy, happiness, gratitude and well-being and four negative emotions (anger, fear, envy and jealousy) (Andrie, 2011). They have designed the team emotion recognition accuracy to measure the member of teammates' emotions to know the intensity of the organizational performance (Elfenbein, Polzer, \& Ambady, 2007a). The organizations have to identify their employees' emotional conditions to cater the team performance (Andries, 2009). The study concentrated on positive and negative affectivity to develop framework and future research (Cropanzano, Weiss, Hale, \& Reb, 2003). The study explained the negative emotions in two ways: one is related to situational (favorable) and another one dispositional (unfavorable) (Karasawa, 1995).

\subsection{Resource depletion}

The study is concentrating on the individual performance rather than the employee performance. Those who have higher baseline resource level have more possible capacity to cope with depleting experiences in the given stipulated period (Trougakos, Beal, Cheng, Hideg, \& Zweig, 2015). The concept has been used in the muscle analogy by regularly citing in the literature of depletion (Muraven \& Baumeister, 2000).

The muscle is represented by the regulatory resources in larger amount and the stronger the muscle, the higher baseline tools of resources are for more time without changing the behavior of depletion. The self-regulatory efforts hang on individual variations, these will drive flow of individuals in specific resource level. In addition, the resources contain two types of activities such as momentary capacity and daily capacity that will enable the immediate demand of the regulatory, in other words, stable baseline of regulatory resources will help the organization in collapse depletion, activities are main sources for regulatory energy to identify the individual regulatory capacity. Most of the individuals draw the resources, which are available to them to resolve the depletion. This will be considered as a central resource depletion.

\subsection{Team member reception}

For the teams to be productive, the organizations should have sufficient human resources and materials, as these factors lead to the constructive success. A sensitive emotional supportive environment always promotes the integrity, sharing, coordinating and amicable environment, which leads to the team becoming more efficient and effective and members also feel very comfortable to support the desired goals of the teams (Erez, Lepine, \& Elms, 2002). Especially, supporting innovative ideas, innovations, thoughts, ways of working environment will be convert into more positive and have an impact of much higher level on team performance (Huckman, Staats, \& Upton, 2009). By having broader less support, the team members will never be hesitating to resume their responsibilities and accountability to de-

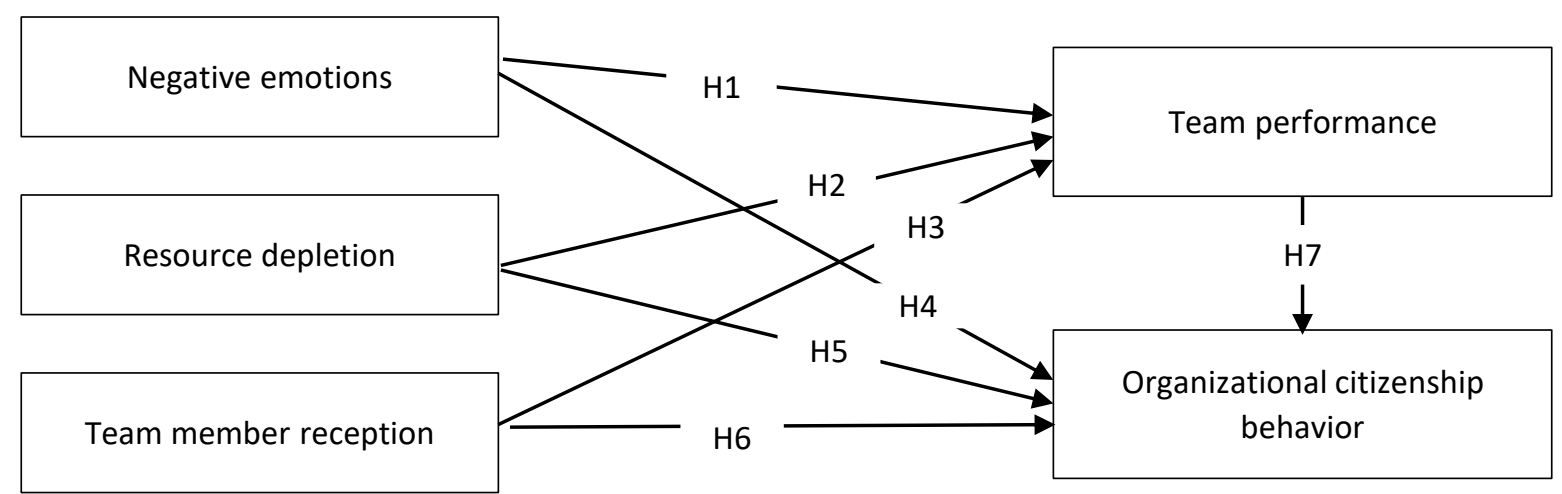

Note: $\mathrm{H}$ indicates hypotheses.

Figure 1. Proposed research framework 
liver their duties, as they well know that all of them are needed in the team to perform better and better.

The literature review revealed that there is a small number of studies has been conducted in this direction, therefore, the researchers made their study to fill this gap.

\section{RESEARCH FRAMEWORK}

\subsection{Hypotheses development}

Taking clue from the prominent theories on team performance and organizational citizenship behavior and the literature review, five factors were found relevant for predicting the relation between the negative emotions, resource depletion, team member reception, team performance and OCB in the present context. In addition, the proposed research framework is shown in Figure 1. Therefore, seven hypotheses concerning each factor were formulated.

Based on the following hypotheses, the discussion was carried out in the present study.

H1: The negative emotions support positively and affect team performance in higher education institutions in India.

H2: The resource depletion showed a favorable influence on team performance.

H3: Team member receptivity showed a positive influence on team performance.

H4: Negative emotions support positively and affect organizational citizenship behavior in higher education institutions in India.

H5: Resource depletion has a confident influence on organizational citizenship behavior.

H6: Team member receptivity has a positive influence on organizational citizenship behavior.

H7: Team performance has a positive influence on organizational citizenship behavior in higher education institutions in India.

\section{RESEARCH METHODS}

\subsection{Participation and procedure}

Participants in the present study were selected from 25 institutions from India. Two separate surveys were administered in two waves to gather the necessary information. In wave 1 , employees were asked to provide information regarding negative emotions, resource depletion, team member receptivity and team performance. In wave 2 (four weeks after wave 1), the questionnaire was distributed to the team leaders to gather the information regarding team performance and team organizational behavior. With regard to our research work, participants were invited to the web-based survey, the researchers received 250 followers including 60 team leaders who participated in the survey. After scrutinizing, our final sample included 204 followers from 51 teams fit for the analysis. The Gender Mean is 1.26, SD is 0.44, Qualification Mean 2.29 is SD 0.86, Number of years in current job Mean is 2.29 , SD is 1.51, Number of years in current profession Mean is 2.94, SD is 1.80 , How long the team members stayed in the team Mean is 1.83 , SD is 1.09 , Average team size Mean is $1.98, \mathrm{SD}$ is 0.57 . Teams consist of between two and nine members, with an average of four members per team.

\subsection{Measures}

The Likert scale of items in our study was 1 = strongly disagree, $5=$ strongly agree, the scale of validity confirmed by the experts (Van alphen, Halfens, Hasman, \& Imbos, 1994). The questionnaire variables items sources have been shown in Table 1.

\subsection{Statistical tools used}

The results of the present study were processed and analyzed through SPSS 25 version, Amos and Mplus 8 version. Structural Equation Modelling (SEM), more specifically, a five-factor model generated, at first Confirmatory Factor Analysis (CFA), were executed to determine the structure of factors the latent constructs and also referred to as latent variable modelling, was performed (Long, 1983a, 1983b; Ullman, 2001; Cantillo, Arellana, \& Rolong, 2015). Finally, the structural model was calculated with means and values inserted into the results of hypotheses. 
Table 1. Source of factors selected

Source: Secondary data.

\begin{tabular}{|c|c|}
\hline Variables & Source(s) \\
\hline Negative emotion & $\begin{array}{l}\text { Van Kleef, Van Doorn, Heerdink, and Koning (2011), Andrie (2011), Connelly and Turel (2016), } \\
\text { Elfenbein, Polzer, and Ambady (2007b), Chang, Johnson, and Yang (2007), Cropanzano, Rupp, } \\
\text { and Byrne (2003) }\end{array}$ \\
\hline Resource depletion & $\begin{array}{l}\text { Maranges, Schmeichel, and Baumeister (2017), Hagger, Wood, Stiff, and Chatzisarantis (2010), } \\
\text { Muraven and Baumeister (2000) }\end{array}$ \\
\hline Team member receptivity & Neha Verma and Santosh Rangnekar (2012), Kane (2011) \\
\hline Team performance & Huckman et al. (2009), Neha Verma, Santosh Rangnekar (2012), Wharton (1993) \\
\hline $\begin{array}{l}\text { Organizational citizenship } \\
\text { behavior (OCB) }\end{array}$ & $\begin{array}{l}\text { Miao and Kim (2009), Katz (1964), Cho and Johanson (2008), Schepman and Zarate (2008), } \\
\text { Chang et al. (2007) }\end{array}$ \\
\hline
\end{tabular}

\section{RESULTS}

\subsection{Analysis of results}

The descriptive statistics of the study reliability coefficient and correlations are presented in Table 2. The reliability coefficient and corrections test was conducted to see the validity of the constructs. (Schreiber, Nora, Stage, Barlow, \& King, 2006) and also conducted the Confirmatory Factor Analysis (CFA) to ensure that negative emotions, resource depletion, team member receptivity, team performance and team organizational citizenship behavior to know correlation construct. The five-factor model fit values are, $x^{2}=4322.987$, Degree of freedom (df) is 199, $p$-value significant at 0.05 level (Digman, 1990). In addition, this baseline model was significant to be superior when compared to any other alternative models in the present study.

Table 2 shows the summary of mean, SD, reliability coefficient and correlations for all the variables. The present study excluded demographic information such as Gender, Qualification, Number of years in current profession, Number of years in current job, Number of years stayed in the same team and Team size. Following Becker's (2005) suggestion, we can exclude those variables from the model. Adding unnecessary control may lead to biased estimates and reduce significant value.

\subsection{Correlation and reliability coefficient analysis}

The correlation and reliability coefficient analysis was conducted between the negative emotions, resource depletion, team member receptivity, team performance, organizational citizenship behaviour, which showed that they are significantly and positively associated with each other.

The negative emotions are with items 4 $(\alpha=0.85)$, resource depletion are with items 5 $(\alpha=0.87)$, team members reception are with items $3(\alpha=0.80)$, team performance items are with items $3(\alpha=0.91)$ and team OCB are with items $5(\alpha=0.90)$. The reliability test is significant (Peterson, 1994), as shown in Table 2.

Table 2. Descriptive statistics, reliability coefficient, and correlations

\begin{tabular}{|c|c|c|c|c|c|c|c|c|c|c|c|c|}
\hline Variable & Mean & SD & 1 & 2 & 3 & 4 & 5 & 6 & 7 & 8 & 9 & 10 \\
\hline Gender & 1.26 & 0.44 & - & - & - & - & - & - & - & - & - & - \\
\hline Qualification & 2.29 & 0.86 & - & - & - & - & - & - & - & - & - & - \\
\hline NYCJ & 2.29 & 1.51 & - & - & - & - & - & - & - & - & - & - \\
\hline NYCP & 2.94 & 1.80 & - & - & - & - & - & - & - & - & - & - \\
\hline NYSST & 1.83 & 1.09 & - & - & - & - & - & - & - & - & - & - \\
\hline Team size & 1.98 & 0.57 & - & - & - & - & - & - & - & - & - & - \\
\hline $\begin{array}{l}\text { Negative } \\
\text { emotions }\end{array}$ & - & - & - & - & - & - & - & - & $(0.85)$ & - & - & - \\
\hline $\begin{array}{l}\text { Resource } \\
\text { depletion }\end{array}$ & - & - & - & - & - & - & - & - & $\begin{array}{l}(0.87) \\
0.61 * *\end{array}$ & - & - & - \\
\hline TMR & - & - & - & - & - & - & - & - & $0.12^{*}$ & $\begin{array}{c}(0.80) \\
0.09\end{array}$ & - & - \\
\hline $\begin{array}{l}\text { Team } \\
\text { performance }\end{array}$ & - & - & - & - & - & - & - & - & $0.91^{* *}$ & $0.36^{* *}$ & $\begin{array}{l}(0.91) \\
0.61 * *\end{array}$ & - \\
\hline Team OCB & - & - & - & - & - & - & - & - & $0.22^{* *}$ & $0.30^{* *}$ & $0.69^{* *}$ & $\begin{array}{l}(0.90) \\
0.87^{* *}\end{array}$ \\
\hline
\end{tabular}

Note: $N=204$, OCB: Organizational citizenship behavior, NYCP: Number of years in current profession, NYCJ: Number of years in current job, NYSST: Number of years stayed in the same team, TMR: team member receptivity. ${ }^{\star} p<.5^{\star *} p<.01$. 


\subsection{Confirmatory Factor Analyses}

The study stability of the scale was tested using structural equation modelling by using Confirmatory Factor Analysis. The measurement model was developed using IBM SPSS Amos 22.0 version and Mplus 8 version. For performing the model fit, varieties of indices were used (Table 3). Thus, the five-factor model with Chi-square statistics of 4322.987, df 199, had a good overall fit to the data.

The discriminant validity and convergence of scales using Confirmatory Factor Analysis was further tested. For the study, composite reliabilities and average variance were used and values were extracted, suggested by Henseler, Ringle, and Sarstedt (2014), and were used for testing convergent validity as shown in Table 3 . Composite Reliabilities (CRs) were found above threshold of 0.70 in each case (Hair et al., 1992). The values for Average Variance Extracted (AVE) were found in the range between 0.65 and 0.80 for all of the constructs. These estimates are found above minimum level of 0.50 (Gerbing \& Anderson, 1988). The results thus established the convergent validity of value with scale.

As suggested by (Gerbing \& Anderson, 1988) were used to check the discriminant validity to prove this test, factor correction among a pair of latent variables should be less than the square root of AVE of each variable as shown in Table 4 by factor correlation matrix.
The examination of this validity test indicates that the square root of AVE of each variable shown in bold cross the diagonal of Table 4 is greater than the correlation value of each pair of variables. The result of this test shows that each construct nominated in this study is different from other. Hence, discriminant validity of the scale is confirmed.

\subsection{Structural equation modelling and hypotheses testing}

The measurement model was converted into structural model to test the proposed hypotheses. The simplified structural model result is shown in Table 5. The hypotheses proposed were tested using RMSEA, CFI, AIC and BIC, shown in Table 5.

In measurement model 1 , negative emotions (4 observed indicators) and team performance (3 observed indicators) are measured, in model 2, resource depletion (5 observed indicators) and team performance ( 3 observed indicators) are measured, in model 3 , team member receptivity (5 observed indicators) and team performance (3 observed indicators) are measured, in model 4 , negative emotions (4 observed indicators) and organizational behavior (5 observed indicators) are measured, in model 5, resource depletion (5 observed indicators) and organizational behavior (5 observed indicators) are measured, in model 6 , team member receptivity (5 observed indicators) and organizational behavior (5 observed indicators) are measured and final model measured team performance ( 3 observed indicators) and organizational

Table 3. The Confirmatory Factor Analysis (CFA) result

\begin{tabular}{c|c|c|c|c}
\multicolumn{1}{c}{ Variables } & $\begin{array}{c}\text { Negative } \\
\text { emotions }\end{array}$ & $\begin{array}{c}\text { Resource } \\
\text { depletion }\end{array}$ & $\begin{array}{c}\text { Team member } \\
\text { receptivity }\end{array}$ & $\begin{array}{c}\text { Team } \\
\text { performance }\end{array}$ \\
\hline Average Variance Extracted & 0.65 & 0.74 & 0.73 & 0.80 \\
Construct Reliability & 0.85 & 0.89 & 0.84 & 0.92 \\
CR: Composite Reliability, AVE: Average Variance Extracted & & 0.91 \\
\hline
\end{tabular}

Table 4. Factor correlation matrix

\begin{tabular}{|c|c|c|c|c|c|}
\hline Variables & Negative emotions & Resource depletion & $\begin{array}{l}\text { Team member } \\
\text { receptivity }\end{array}$ & $\begin{array}{c}\text { Team } \\
\text { performance }\end{array}$ & OCB \\
\hline Negative emotions & $(0.65)$ & - & - & - & - \\
\hline Resource depletion & 0.05 & $(0.74)$ & - & - & - \\
\hline Team member receptivity & 0.01 & 0.36 & $(0.73)$ & - & - \\
\hline Team performance & 0.06 & 0.29 & 0.29 & $(0.80)$ & - \\
\hline OCB & 0.10 & 0.49 & 0.49 & 0.40 & $(0.79)$ \\
\hline
\end{tabular}


Table 5. Changes in the fit statistics in confirmatory analysis of all variables of the study

\begin{tabular}{c|c|c|c|c|c|c|c|c}
\multicolumn{10}{c}{ Source: Primary data. } \\
\hline Models & Path & X2 & df & RMSEA & CF1 & TLI & AIC & BIC \\
\hline$M-1$ & NE $\rightarrow$ TP & 60.79 & 8 & 0.180 & 0.934 & 0.876 & 2815.889 & 2878.933 \\
\hline$M-2$ & RD $\rightarrow$ TP & 140.603 & 10 & 0.285 & 0.876 & 0.767 & 2647.066 & 2700.110 \\
\hline$M-3$ & TMR $\rightarrow$ TP & 160.687 & 9 & 0.306 & 0.861 & 0.739 & 2630.462 & 2693.507 \\
$M-4$ & NE $\rightarrow$ OCB & 100.439 & 10 & 0.238 & 0.867 & 0.751 & 3032.871 & 3095.916 \\
\hline$M-5$ & RD $\rightarrow$ OCB & 103.521 & 8 & 0.242 & 0.890 & 0.795 & 2880.393 & 2943.438 \\
\hline$M-6$ & TMR $\rightarrow$ OCB & 202.109 & 9 & 0.345 & 0.811 & 0.645 & 2819.266 & 2882.310 \\
\hline$M-7$ & TP $\rightarrow$ OCB & 107.141 & 11 & 0.246 & 0.921 & 0.852 & 2394.248 & 2457.248 \\
\hline
\end{tabular}

Note: NE: Negative Emotions, RD: Resource Depletion, TMR: Team Member Receptivity, TP: Team Performance, OCB: Organizational Citizenship Behavior, CFI: Confirmatory Fit Index, TLI: Tucker Lewis Index, AIC: Akaike Information Criterion, BIC: Bayesian Information Criterion, ${ }^{*} p<.05^{* *}<.01$.

behavior (5 observed indicators), and their baseline model for every latin variable in model 1 (negative emotions and team performance), the baseline model fit values are as follows: Chi-square is 907.928, df is 15 and SRMSR (Standardized Root Mean Square Residual) is 0.092 significant at $<.01$, in model 2 , for resource depletion and team performance, the baseline Chi-square value is 1082.548 , $\mathrm{df}$ is 16, SRMR is 0.063 significant at $<.05$.

In model 3, for team member reception and team performance, the baseline model fit values are as follows: Chi-square value is $1112.857, \mathrm{df}$ is 14 , SRMSR is 0.074 , significant at $<.05$. In model 4 , for negative emotions and organizational citizenship behavior, the baseline model fit values are as follows: Chi-square is $865.477, \mathrm{df}$ is 17 and SRMSR is 0.073 , significant at $<.05$. In model 5 , for resource depletion and organizational citizenship behavior, the baseline Chi-square value is 1046.631 , df is 55 , SRMSR is 0.104 , significant at $<.01$. In model 6 , for team member reception and organizational citizenship behavior, the baseline model fit values are as follows: Chi-square 1110.374, $\mathrm{df}$ is 18 , SRMSR is 0.060 , significant at $<.01$ and in model 7 , for team performance and organizational citizenship behavior, the baseline model fit values are as follows: Chi-square value is $1401.251, \mathrm{df}$ is 16 , SRMSR is 0.039 , significant at $<.01$.

The study adopted statistical measurement model and its other measurement models are presented in Table 5. Model 7 fitted all data best as fixed compared to BIC and AIC significant values (the better fit value is the lowest). Other fit indicators were also considered to the model fit, including all the values such as Chi-square, CFI,TFI and RMSEA (Schermelleh-Engel, Moosbrugger, \&
Müller, 2003; Bentler, 1999), the values presented in the study have a good fit to the model and their values of CFI and TLI were higher than the value of 0.95 and other values such as RMSEA also show the significant values and were found between 0.80 and 0.05 and, overall, the values are significant. Therefore, we have concluded that the items are loaded significantly.

\section{DISCUSSIONS}

The study investigated the link between the negative emotions, resource depletion, team member receptivity, team performance and organizational citizenship behavior. We extended theory and research on OCB by accounting for team and individual level in higher education institutions. The relationship between negative emotions, resource depletion, team member receptivity, team performance and organizational citizenship behavior is examined. The present study findings clearly indicate that team performance influenced OCB via negative emotions, resource depletion, team member receptivity, team performance and organizational citizenship behavior. Through the hypotheses, the study found that there is a significant relationship between the variables that indicates that negative emotions, resource depletion, team member receptivity, team performance and organizational citizenship behavior are related to each other them.

The present study adopted 7 hypotheses, all are established through statistical results, in detail, the first one is designed on the negative emotions by the variables such as irritable, upset, hostile and angry having a positive influence on the team per- 
formance. In the second hypothesis, focusing on resource depletion had a positive influence on the team performance by having variables such as will power, unfocused, taking lot of time to concentrate on something while working and absorbing any information. The third hypothesis proved that the there is an influence on the team performance by having variables such as members are allowing for new ideas, suggestions, showing interest of other's ideas, accepting new ideas from others and not dismissing the suggestions.

In fourth hypothesis, negative emotions were explained by using variables such as irritable, upset, hostile and angry. As for its influence on the organizational citizenship behavior, fifth hypothesis described and proved its significance for the organizational citizenship behavior by having variables such as will power, unfocused, taking lot of time to concentrate on something while working and absorbing any information, sixth hypothesis explains the team members receptivity by having variables such as allowing for new ideas, suggestions, showing interest of other's ideas, accepting new from others and not dismissing the suggestions of others on organizational citizenship behavior and the ideas in seventh hypothesis supported the influence on the organizational citizenship behavior and that there is a correlation between the team performance and organizational citizenship behavior by using variables such as team very competent while reaching the tasks, team get its work done very effectively while working and team has performed well in the given job in the selected higher education institutions in India.

\subsection{Implication}

The research has important theoretical contributions, apart from the findings that may have some interesting implications for higher education institutions. Organizational citizenship behavior is very important for enhancing team perfor- mance, delivering spontaneous behavior, so that the administers and academics cannot snub. The employees if they have negative emotions and resource depletion may be afraid and it will produce negative performance, and it leads to native organizational performance. So, the administrators of the higher education institutions need to adopt the procedure in order to eradicate the employees' negative emotions and resource depletion from their workplace, on the other hand, it needs to improve their team member receptivity in the work environment. The higher education institutions have to concentrate on this direction to overcome these activities. Therefore, the practitioners and consultants and OD practitioners may design and run seminars, workshops, conferences and specialized training programs for improving organizational citizenship behavior, based on the reference model of proposed research framework used in the present study.

\subsection{Limitations and future research}

The present study draws some conclusions through the empirical research and came up with some contributions in the theory and practice. There are some limitations for the study: firstly, the present study has taken small sample size, it can be expanded to more representatives in the future research, secondly, having the same nature, this study can be extended to other countries/continents, third, in order to draw the meaningful conclusion from the model, it is considered that negative emotions, resource depletion, team member receptivity, team performance and organizational citizenship behavior, the next study can be done separately by having three or four factors as a mod$\mathrm{el}$, fourth, the effect of negative emotions on team performance would lead to richer organizational citizenship behavior, in addition, it may also find it valuable to consider additional moderating variable. Therefore, the researchers should continue to explore various mechanisms to handle conditions of OCB in the higher education sphere.

\section{CONCLUSION}

The employees will contribute more to organizations when they are in comfortable zone, this will add value to the team and enhance the performance as well. The present study sheds new light on negative emotions, resource depletion, team members' receptivity, team performance linking to higher educa- 
tion institutions employees' OCB. The study findings indicated that negative emotions, resource depletion, team members' receptivity, team performance are interlinked to the OCB in the environment of Indian higher education intuitions.

As a result of this study, it is evident that the dimension of team performance is highly associated with OCB. The study also reveals that negative emotions, resource depletion, team member receptivity have highly positive impact on team performance in their organizational citizenship behavior (OCB). Moreover, India is more group-oriented than individual-oriented. Therefore, most of the individuals show most interest working in teams in order to perform better.

There are various factors responsible for the overall success of an organization. But negative emotions, resource depletion, team members receptivity, team performance are considered the most important factors in the success of Indian higher education institutions such as organizational citizenship behavior $(\mathrm{OCB})$.

\section{REFERENCES}

1. Andrie, A. M. (2011). Positive and Negative Emotions Within The Organizational Context. Global Journal of Human Social Science, 11(9), 26-39.

2. Andries, A. (2009). Emotions management within organizations. Economics and Applied Informatics, 2(1), 17-34. Retrieved from http:// ideas.repec.org/a/ddj/fseeai/ y2009i2p17-34.html

3. Bateman, T. S. (1983). Job Satisfaction and the Good Soldier: The Relationship Between Affect and Employee Citizenship. Academy of Management Journal, 26(4), 587-595.

4. Becker, T. E. (2005). Potential Problems in the Statistical Control of Variables in Organizational Research: A Qualitative Analysis with Recommendations. Organizational Research Methods, 8(3), 274-289. https://doi. org/10.1177/1094428105278021

5. Bentler, P. M., \& Hu L. (1999). Cutoff criteria for fit indexes in covariance structure analysis: Conventional criteria versus new alternatives. Structural Equation Modeling: A Multidisciplinary Journal, 6(1), 1-56.

6. Campo, M., Champely, S., Lane, A. M., Rosnet, E., Ferrand, C., \& Louvet, B. (2016). Emotions and performance in rugby. Journal of Sport and Health Science, 1-10. https://doi.org/10.1016/j. jshs.2016.05.007
7. Cantillo, V., Arellana, J., \& Rolong, M. (2015). Modelling pedestrian crossing behaviour in urban roads: A latent variable approach. Transportation Research Part F: Traffic Psychology and Behaviour, 32, 56-67. https://doi. org/10.1016/j.trf.2015.04.008

8. Chang, C. H., Johnson, R. E., \& Yang, L. Q. (2007). Emotional strain and organizational citizenship behaviours: A metaanalysis and review. Work and Stress, 21(4), 312-332. https://doi. org/10.1080/02678370701758124

9. Chester I. Barnard (1984). The Functions of the Executive. Harvard University Press, 11(2), 82-95. https://doi.org/10.5465/ AMR.1986.4283878

10. Cho, S., \& Johanson, M. M. (2008). Organizational Citizenship Behaviour and Employee Performance: A Moderating Effect of Work Status in Restaurant Employees. Journal of Hospitality \& Tourism Research, 32(3), 307-326. https://doi. org/10.1177/1096348008317390

11. Connelly, C. E., \& Turel, O. (2016). Effects of team emotional authenticity on virtual team performance. Frontiers in Psychology, 7(AUG). https://doi. org/10.3389/fpsyg.2016.01336

12. Cropanzano, R., Rupp, D. E., \& Byrne, Z. S. (2003). The relationship of emotional exhaustion to work attitudes, job performance, and organizational citizenship behaviours. Journal of Applied Psychology, 88(1), 160-169. https://doi.org/10.1037/00219010.88.1.160

13. Cropanzano, R., Weiss, H. M., Hale, J. M. S., \& Reb, J. (2003). The structure of affect: Reconsidering the relationship between negative and positive affectivity. Journal of Management, 29(6), 831-857. https://doi.org/10.1016/S01492063(03)00081-3

14. Digman, J. M. (1990). Personality structure: Emergency of the Five Factor Model. Annu Rev Psychol, 417-440.

15. Døjbak Håkonsson, D., Eskildsen, J. K., Argote, L., Mønster, D., Burton, R. M., \& Obel, B. (2016). Exploration versus exploitation: Emotions and performance as antecedents and consequences of team decisions. Strategic Management Journal, 37(6), 9851001. https://doi.org/10.1002/ smj.2380

16. Elfenbein, H. A., Polzer, J. T., \& Ambady, N. (2007a). Chapter 4 Team Emotion Recognition Accuracy and Team Performance. Research on Emotion in Organizations, 3, 87-119. https://doi.org/10.1016/S17469791(07)03004-0

17. Elfenbein, H. A., Polzer, J. T., \& Ambady, N. (2007b). 
Chapter 4 Team Emotion Recognition Accuracy and Team Performance. Research on Emotion in Organizations. https://doi.org/10.1016/S17469791(07)03004-0

18. Erez, A., Lepine, J. A., \& Elms, H. (2002). Effects of rotated leadership and peer evaluation on the functioning and effectiveness of self-managed teams: A quasiexperiment. Personnel Psychology, 55(4), 929-948. https://doi. org/10.1111/j.1744-6570.2002 tb00135.x

19. Ganesh, M. P., \& Gupta, M. (2010). Impact of virtualness and task interdependence on extra-role performance in software development teams. Team Performance Management: An International Journal, 16(3/4), 169-186. https://doi. org/10.1108/13527591011053250

20. Gardner, W. L., Fischer, D., \& Hunt, J. G. (Jerry. (2009). Emotional labor and leadership: A threat to authenticity? Leadership Quarterly, 20(3), 466482. https://doi.org/10.1016/j. leaqua.2009.03.011

21. Gerbing, D. W., \& Anderson, J. C. (1988). An Updated Paradigm for Scale Development Incorporating Unidimensionality and Its Assessment. Journal of Marketing Research, 25(2), 186-192. https:// doi.org/10.2307/3172650

22. Hagger, M. S., Wood, C., Stiff, C., \& Chatzisarantis, N. L. D. (2010). Ego depletion and the strength model of self-control: A metaanalysis. Psychological Bulletin, 136(4), 495-525. https://doi. org/10.1037/a0019486

23. Henseler, J., Ringle, C. M., \& Sarstedt, M. (2014). A new criterion for assessing discriminant validity in variancebased structural equation modeling. Journal of the Academy of Marketing Science, 43(1), 115135. https://doi.org/10.1007/ s11747-014-0403-8

24. Huckman, R. S., Staats, B. R. \& Upton, D. M. (2009). Team Familiarity, Role Experience, and Performance: Evidence from Indian Software Services.
Management Science, 55(1), 85-100. https://doi.org/10.1287/ mnsc. 1080.0921

25. Kahn, D. katz. (1996). This Week's Citation Classic. Science, 1(34), 1993.

26. Kane, A. A. (2011). Neecomers as active agents: Team Receptivity to Integrating vs Differentiating Identity Strategies. Academy of Management Annual Meeting Proceedings, 1. https:// doi.org/10.5465/AMBPP.2011.65869733

27. Karasawa, K. (1995). An Attributional Analysis of Reactions to Negative Emotions. Personality and Social Psychology Bulletin, 21(5), 456-467. https://doi. org/10.1177/0146167295215004

28. Katz, D. (1964). The motivational basis of organisational behaviour. Behavioural Science, 9(2), 131146. https://doi.org/10.1002/ bs.3830090206

29. Lee, V. E., Dedrick, R. F., \& Smith, J. B. (1991). The Effect of the Social Organization of Schools on Teachers' Efficacy and Satisfaction. Sociology of Education, 64(3), 190-208. https:// doi.org/10.2307/2112851

30. Long, J. S. (1983a). Confirmatory factor analysis: A preface to LISREL. Beverly Hills, CA: Sage.

31. Long, J. S. (1983b). Covariance structure models: An introduction to LISREL. Beverly Hills, CA: Sage.

32. Maranges, H. M., Schmeichel, B. J., \& Baumeister, R. F. (2017). Comparing cognitive load and self-regulatory depletion: Effects on emotions and cognitions. Learning and Instruction, 51, 74-84. https://doi.org/10.1016/j. learninstruc.2016.10.010

33. Miao, R.-T., \& Kim, H.-G. (2009). The Impact of Organizational Citizenship Behaviour on Team Effectiveness in China: The Moderating Role of Task Complexity. In 2009 Fourth International Conference on Computer Sciences and Convergence Information Technology (pp. 641-646). https:// doi.org/10.1109/ICCIT.2009.200
34. Muraven, M., \& Baumeister, R. F. (2000). Self-regulation and depletion of limited resources: Does self-control resemble a muscle? Psychological Bulletin 126(2), 247-259. https://doi. org/10.1037/0033-2909.126.2.247

35. Neha Verma, Santosh Rangnekar, M. K. B. (2012). Team Effectiveness in Indian Organizations: A Comparative Analysis of Public and Private Sector. Delhi Business Review, 13(2), 43-54.

36. Organ, D. W., \& Konovsky, M. (1989). Cognitive versus affective determinants of organizational citizenship behaviour. Journal of Applied Psychology, 74(1), 157-164. https://doi.org/10.1037/00219010.74.1.157

37. Organ, \& Ryan. (1995). A MetaAnalytic Review of Attitudinal and Dispositinal Predictors of Organizational Citizenship Behaviour. Personnel Psychology, 48(4), 775-802. https://doi org/10.1111/j.1744-6570.1995. tb01781.x

38. Peterson, R. A. (1994). A MetaAnalysis of Cronbach's Coefficient Alpha. Journal of Consumer Research, 21(2), 381-391. https:// doi.org/10.1086/209405

39. Podsakoff, P. M., \& MacKenzie, S. B. (1997). Impact of Organizational Citizenship Behaviour on Organizational Performance: A Review and Suggestion for Future Research. Human Performance, 10(2), 133-151. https://doi.org/10.1207/ s15327043hup1002_5

40. Schepman, S., \& Zarate, M. (2008). The Relationship between Burnout, Negative Affectivity and Organizational Citizenship Behaviour for Human Services Employees. International Journal of Humanities and Social Sciences, 2(4), 216-222.

41. Schermelleh-Engel, K., Moosbrugger, H., \& Müller, H. (2003). Evaluating the Fit of Structural Equation Models: Tests of Significance and Descriptive Goodness-of-Fit Measures. Methods of Psychological Research Online, 8(2), 23-74. 
42. Schreiber, J. B., Nora, A., Stage, F. K., Barlow, E. A., \& King, J. (2006). Reporting Structural Equation Modeling and Confirmatory Factor Analysis Results: A Review. The Journal of Educational Research, 99(6), 323-338. https://doi.org/10.3200/ JOER.99.6.323-338

43. Sharma, J., Bajpai, N., \& Holani, U. (2011). Organizational Citizenship Behaviour in public and private sector and its impact on job satisfaction: a comparative study in indian perspective. International Journal of Business and Management, 6(1), 67-75.

44. Singh, A. K., \& Singh, A. P. (2009). Does Personality Predict Organisational Citizenship Behaviour among Managerial Personnel. Journal of the Indian Academy of Applied Psychology, 35(2), 291-298.
45. Ton, Z., \& Huckman, R. S. (2008). Managing the Impact of Employee Turnover on Performance: The Role of Process Conformance. Organization Science, 19(1), 56-68. https://doi.org/10.1287/ orsc. 1070.0294

46. Trougakos, J. P., Beal, D. J., Cheng, B. H., Hideg, I., \& Zweig, D. (2015). Too drained to help: A resource depletion perspective on daily interpersonal citizenship behaviours. Journal of Applied Psychology, 100(1), 227-236. https://doi.org/10.1037/a0038082

47. Van alphen, A., Halfens, R., Hasman, A., \& Imbos, T. (1994). Likert or Rasch? Nothing is more applicable than good theory. Journal of Advanced Nursing, 20(1), 196-201. https://doi.org/10.1046/ j.1365-2648.1994.20010196.x

48. Van Kleef, G. A., Van Doorn, E. A. Heerdink, M. W., \& Koning, L. F. (2011). Emotion is for influence.
European Review of Social Psychology, 22(1), 114-163. https:// doi.org/10.1080/10463283.2011.6 27192

49. Ullman, J. B. (2001). Structural equation modeling. In B. G. Tabachnick \& L. S. Fidell (Eds.), Using multivariate statistics (4th ed.). Needham Heights, MA: Allyn \& Bacon.

50. Wharton, A. S. (1993). The Affective Consequences of Service Work. Work and Occupations, 20(2), 205-232. https://doi.org/10.1 177/0730888493020002004

51. Yen, H. R., \& Niehoff, B. P. (2004). Organizational Citizenship Behaviours and Organizational Effectiveness: Examining Relationships in Taiwanese Banks. Journal of Applied Social Psychology 34(8), 1617-1637. https://doi. org/10.1111/j.1559-1816.2004. tb02790.x 